\title{
It's Not Easy Being Green: Integrating Refugees in Ger- man Environmentalist Culture
}

\section{Joela Jacobs}

A short documentary series, entitled "Der Ökofimmel: Wie Umweltschutz der Umwelt schadet" (Eco Mania: How Environmentalism Hurts the Environment) by German news outlet Spiegel TV Magazin from 2012 features an employee of Berliner Stadtwerke (Berlin's public utility company) demonstrating proper recycling etiquette to a journalist who seems intent on tripping him up (Neubacher, 00:02:43-00:03:49). ${ }^{1}$ The latter has brought a range of items that are particularly hazardous or difficult to sort, such as chemicals and multi-material products. Faced with a container of toilet bowl cleaner, the employee immediately identifies it as plastic, yet the journalist points out that a small remainder of the cleaner is still inside. When the journalist suggests discarding the final drops of the cleaner in the toilet, the employee is adamant that chemicals do not belong there. Since toilet bowl cleaner is typically poured into the toilet for cleaning, the bemused journalist repeatedly asks the employee to explain why it would be wrong to do so now; yet the increasingly flustered employee continues to insist on the standard procedures for discarding leftover chemicals. When examining environmentalist behaviours, such as this video aims to do, some paradoxical routines and beliefs come to light, which are often fiercely defended by their practitioners, even though they are unable to explain their reasons. Though the documentary's goal is to uncover habits and systemic issues that undermine the efficacy of the largely very successful environmental practices in Germany, one of its side effects is to

\footnotetext{
${ }^{1}$ My thanks go to Dr. James McCormick for pointing me to this source, while brainstorming ideas for teaching German environmentalism in US colleges together. All renditions and translations of German media coverage in this article are mine, since none of the documentary videos and newspaper articles have appeared in English.
} 
show that environmentalism is a cultural product. The string of interviews and encounters in the documentary shows that environmentalist practices are culturally and historically shaped phenomena that are particular to their respective contexts and dependent on cultural representatives.

Looking for environmentalist practices that "hurt the environment" (as the documentary's subtitle asserts) in a country that is widely considered a long-standing "green leader" seems like a misplaced act of criticism at first. Holding fast to environmental traditions, whether they are effective or not can, however, spell both success and failure in established environmentalist systems such as the German one. During a visit to a recycling facility in Bonn a few years ago, the employees told me that Germany has plans of switching to single-sort recycling, "like the USA," reasoning that it is more efficient and effective to have a combination of machines and professionals sort materials. ${ }^{2}$ Yet, they said, the deeply ingrained recycling conventions make convincing the public the most difficult aspect of this endeavour (a fact that seems to be confirmed by the deep-seated scepticism with which German visitors tend to approach the single-sort bin in my home in the US). It appears that established environmentalist infrastructures face difficulties when adapting to newer or different technologies at least in part because they have fallen victim to their historically and publicly established success. Even or perhaps particularly those countries that are perceived as environmental pioneers can find their extensive environmentalist systems thwarted by an adherence to the particularities of those structures that border on dogmatic devotion - that is, its practitioners believe that there is only one way to protect the environment effectively. Take

\footnotetext{
${ }^{2}$ Whether or not these plans are accurate or mere speculation, the greater efficiency of one recycling system over another is a complex and highly debated matter, since it involves many factors that have to be weighed against one another. Ranging from financial considerations to practical concerns, these factors ultimately make the decision about greater efficiency one that has to take into account the existing environmental infrastructure of the country as well as its culture of environmentalism.
} 
another example, the seemingly widespread German household practice of putting plastic packaging like yogurt containers in the dishwasher before depositing them in the appropriate recycling bin: the idea that the citizen's responsibility in the recycling process is only fulfilled when items are separated from all other materials is carried to excess by cleaning degradable residue that would be removed at the recycling plant. ${ }^{3}$ This habit is supported by the central position of recycling in German everyday life, which seems at times almost synonymous with environmentalism writ large, making the appropriate disposal of recyclables appear more important than conserving water and energy. ${ }^{4}$

The cultural specificity of environmentalist behaviour becomes most evident when those who have not grown up with the same routines try to adapt to them, which is why this article will examine the depiction of this process in media coverage of initiatives that teach recent refugees about German environmentalist culture as an integrative measure. Well-established practices of everyday environmentalism often require extensive knowledge, which sets cultural outsiders up for failure (while also often challenging cultural insiders). The Spiegel TV documentary takes on the German recycling system for a reason: it relies on a colour-coded system of at least four different depositories, which varies by Bundesland (federal state). The number of bins in this system easily swells into double digits when considering not just types of plastics, paper, organic waste, and trash, but also glass (sorted by colour), bottle corks, batteries, printer cartridges, fabric, bulky items, and various kinds of chemicals, electronics, and metals. Knowing where to deposit one's trash requires comprehending complex labels, both on

\footnotetext{
${ }^{3}$ The guidelines for the rinsing of recyclables have changed with the advent of more efficient sorting machines, which explains this older habit (Dallmus). Interestingly, the mandate to rinse varies in the US by municipal unit (Simmons).

${ }^{4}$ The limits and the relative value of recycling have been discussed, particularly in respect of the conservation of other resources, since its inception (Speck, p. 170 and Tierney).
} 
the item and the bin, and many cities have recycling guides of several pages that list items from "dog poop" to "dust" to help residents avoid fines for unlawful disposal (cf. Technische Betriebe Solingen). Though directed by global guidelines and often imagined as universally understood, environmentalism turns out to be deeply idiosyncratic and varies according cultural context, a difference which can be as minimal as the border between one county and the next. Acquiring or sustaining one's own environmentalism in a different cultural context therefore requires extensive adaption and learning - a process that is defined as much by one's own cultural convictions as by the values of the adopted culture, and which brings out contradictions that can be difficult to resolve.

In the wake of the so-called "refugee crisis" involving the arrival of large numbers of people from Syria, Iraq, Afghanistan, West Africa, and other countries in 2015, the receiving European countries, among them Germany, have been instituting many programs geared at easing the transition of the new arrivals into the societies in which they have been settling. These programs ideally take into account the needs of both sides, new arrivals and locals, yet public debates in Germany quickly showed that the priorities for those programs varied widely across the board: while the acquisition of the German language and, with it, learning about access to basic needs, such as food, medical care, information technology, schooling, work, etc. in the new country were largely shared immediate goals, certain aspects of cultural learning were weighted quite differently within and across various groups involved in these conversations. Topics such as spaces for Muslim religious life or cultural training in respect to gender were particularly hotly debated. ${ }^{6}$ Tinged by fears from both sides and lacking models for how to achieve "success" in these arenas, such discussions

\footnotetext{
${ }^{5}$ Several voices have suggested the term solidarity crisis instead, placing the burden not on those who are most affected by it, but rather on their reception (e.g. Ki-moon).

${ }^{6}$ See examples like Reimann and Klovert.
} 
were additionally complicated by incidents such as two deadly terror attacks by Islamists in Paris in 2015 and Brussels in 2016 and the high numbers of sexual assaults reported in Cologne and other German cities on New Year's Eve 2015 that were ultimately attributed to groups of men from Northern Africa (Amjahid et al.). Yet, outside the headlines, many private citizen initiatives, clubs, groups, and municipal agencies devised ways of making the focal point of their work in the public sphere accessible to refugees and creating spaces of encounter between current and potential future citizens, in order to foster mutual learning. Among these are many environmental initiatives, whose varied programs document the fact that environmentalism is perceived as a German cultural value about which new arrivals need to learn. As the Director of a municipal waste management agency put it in the context of one such initiative: "In Deutschland ist Mülltrennung zum Kulturgut geworden. (In Germany, recycling has become a cultural value.)" (Messerschmidt, n. p.)

This conviction is widely held and supported by the German government. The Deutsche Bundesstiftung Umwelt (German Federal Environmental Foundation), for instance, set aside a 125,000 Euro grant supporting projects focusing on the environmental education of refugees with up to 10,000 Euro each. One of the winning ventures is the Bavarian program "Umweltbildung mit Flüchtlingen" (Environmental Education with Refugees) of the Arbeitsgemeinschaft Natur- und Umweltbildung (Working Group for Nature and Environmental Education), which gathered various local initiatives on a website (www.umweltbildung-mit-fluechtlingen.de). It is meant to be a resource for citizens looking to engage in the environmental education of refugees, but it also intends to foster expansion, collaboration, and exchange between existing programs by sharing materials, project ideas, funding and training opportunities. Among the projects are youth excursions into forests and reserves that involve hands-on language learning with locals, and "intercultural gardens," in which local and refugee women plant crops of typically German vegetables and herbs 
alongside produce that is important in the latter's native cuisine, and then trade recipes and ultimately cook together at regular meetings. Other programs have elementary school classes where many new students from other countries plant trees together so they can get to know each other outside of the classroom, or bring together groups of men for a day of cleaning up a riverside (see "Alle Projekte von A-Z"). Most initiatives focus on specific demographic groups among the refugees, such as families, unaccompanied minors, mothers, children of a certain age, or single men, in order to match the activities to their interests and connect them with peers; yet by doing so, they also reinforce traditional gender roles and create divisions. Many of the projects emphasize the importance of encounters between long-time residents and new arrivals that are organized around a shared activity in order to foster interpersonal, linguistic, cultural, and topical learning processes simultaneously. Some programs specifically cater to adolescents and adults who are not yet allowed to work under refugee and asylum laws ${ }^{7}$ and are therefore particularly interested in spending their time productively, or consider this a way of giving back to the country that has taken them in. ${ }^{8}$

News coverage about the practical experiences with these projects tends to focus on three aspects that reveal much about German cultural conceptions of environmentalism: 1) environmentalism is (supposedly) an entirely new idea to refugees, ${ }^{9}$

\footnotetext{
${ }^{7}$ Work permit regulations depend on the stage the applicant is at in his or her refugee or asylum claim. In addition they may vary by country of origin (Bundesministerium für Arbeit).

${ }^{8}$ Many "thank you" events organized by refugees have taken place, ranging from writing letters and cards to handing out roses and cakes, and even hosting full meals for their German neighbours. Several events also involved picking up trash and trimming hedges in public spaces, such as "Müll sammeln als Dankeschön" and "Einsatz für ein sauberes Heidelsheim."

${ }^{9}$ Most articles proceed from the assumption that there are no environmental practices whatsoever in the refugee's home countries, ignoring any existing initiatives (cf. for instance www.ecomena.org, an environmental platform
} 
2) environmentalism is important to succeed in German everyday life, and 3) environmentalism is complicated and requires education. ${ }^{10}$ Many of the articles begin their narrative with images of trash, be it pictured or described:

Es ist leider ein vertrautes Bild: Auf dem Gelände einer Flüchtlingsunterkunft im Landkreis Fürstenfeldbruck liegt Müll. Verteilt auf den Wegen, zwischen den Fahrrädern, die vor dem Haus abgestellt sind und im Rasen rund um das Gebäude. Sogar außerhalb des Zaunes liegt der Abfall. Papier, Plastiktüten, Verpackungsmaterial. Die Mülltonnen quellen über. In ihnen stecken sämtliche Überreste westlichen Konsumalltags. Ungetrennt! Zugegeben, auch die Einheimischen sind nicht immer Musterknaben im Müllvermeiden und Mülltrennen. Aber Menschen aus anderen Kulturen kennen weder die Regeln dafür, noch deren Sinn. Und das kann zu Problemen führen.

It is unfortunately a familiar image: there is trash all over the grounds of a housing area for refugees in the district of Fürstenfeldbruck. Scattered on the paths, between the bikes parked in front of the house, and on the grassy areas around the building. Even outside of the fence there is trash. Paper, plastic bags, packaging materials. The trash cans are spilling over. They contain all the residue of Western consumerist everyday life. Unseparated! Admittedly, the locals are also not always models of reducing and recycling

for and about environmentalism in the Middle East and North Africa) and equating the absence of a systematic environmentalist infrastructure in wartorn and poor regions with a lack of awareness and/or education that ignores global information flow. The project organizer of the environmental initiative Ankommen und Verstehen, for instance, is quoted as saying: "Das liegt aber auch daran, dass die Menschen, die zu uns kommen, in ihren Heimatländern noch nichts über Mülltrennung gehört haben. Da wird der Müll zum Teil auf der Straße entsorgt oder angezündet. Das heißt, sie müssen hier erst lernen, wie mit dem Abfall umzugehen ist. (This is because the people who come to us have not heard anything about recycling in their home countries. There, trash is sometimes disposed of in the street or burned. That means that they have to learn here how to deal with trash to begin with.)" (Hackl, n. p.) Ironically, large quantities of recyclables end up being burned in Germany because they exceed the legally required recycling quota ("Verbrannt statt wiederverwertet").

${ }^{10} \mathrm{Cf}$., for instance, Hackl, Messerschmidt, and Verein Menschen leben. 
trash. But people from other cultures know neither the rules for it, nor their purpose. And that can lead to problems. (Hackl, n. p.)

The abundance of trash in places where it does not belong does not only undermine the ideal of recycling, it also evokes a certain chaos and otherness that is in conflict with stereotypical notions of German order and the idyllic home. The vivid images in these short sentences give the impression that these refugees have not fully arrived, and have not yet found, been given, or made a home because the surroundings of their shelter are not treated with the care their German neighbours expect of them. On the metaphorical level, this trash is as out of place as the migrants themselves: it is not integrated into the categories of the larger system, thus echoing both the principle of recycling and the problematic notion of "integration." Asylum housing is notorious for being in remote locations, keeping its residents, who come from a variety of countries and cultural backgrounds, isolated from German life (Hummitzsch). Yet trash beyond the fence and "Unseparated!" waste seem to threaten this partition. "All the residue of Western consumerist everyday life" in the overflowing trash cans is a statement that accuses the residents of having acquired local tastes to excess. Such a charge, however, does not take into account the idea that people who arrive with no more than they can carry may have a greater need to acquire new items of every-day life than their well-established neighbours who can engage in trash reduction and minimalist living by choice. Moreover, emptying the overflowing trash cans at adequate intervals is, in fact, the responsibility of the local municipality rather than that of the refugees. Ironically, the above statements lump together all "people from other cultures" in an "Unseparated!" manner. While excusing their environmental ignorance, such blanket judgements come across as ignorant themselves despite what are presumably the best of intentions. Bringing together notions of refuse and refuge in its carefully engineered rhetoric, the article's opening sentences betray a deep ambivalence towards the disruption of established routines by cultural outsid- 
ers, indeed the disruption of the "boundaries" of the German nation (Kulturnation) as a whole. In this context, recycling becomes a metaphor for integration as a model that leaves no "waste" by striving to eliminate "the other."

The text goes on to detail the refugee initiative Ankommen und Verstehen (Arriving and Understanding), which helps individual refugees become trash and energy experts through a 30-hour program that combines independent research with practical training and excursions. After the course, the new experts are expected to teach other refugees in their daily lives. The initiative has a dual goal that blurs the boundaries between environmental and societal concerns: "Die Geflüchteten und Asylsuchenden sollen den bewussten Umgang mit Ressourcen erlernen - und so besser Teil unserer Gesellschaft werden. (The refugees and asylum seekers should learn about the conscious handling of resources - and thereby become better integrated into our society.)" (Hackl, n. p.) This twofold purpose requires, in the words of the beginning of the article, an understanding of both the "rules and their purpose," which will not only help the environment, but will also be an essential factor in the refugees' "integration" into German society, as the project organizer, Birgit Baindl, explains:

Wer die Werte unserer Gesellschaft kennenlernt, wer versteht wie auch unsere Ressourcen geschützt werden, der wird Teil dieser Gesellschaft. Und umgekehrt wird der von der Gesellschaft geachtet. Weil die Menschen dann sehen, die Neuankömmlinge teilen diese Werte mit Ihnen [sic!] und setzen sie auch engagiert um.

Whoever gets to know about the values of our society, who understands also how our resources are protected, becomes part of this society. And he is respected by society in return. Because, then, people see that the new arrivals share these values with them and put them into practice actively. (Hackl, n. p.)

Though referring to environmental practices specifically, this statement regarding learning about cultural values could be applied to any aspect of the debates about helping refugees transition into German society. It is therefore all the more problemat- 
ic that this statement requests that the German cultural values be incorporated in exchange for respect (which should be given as a matter of course) and places the burden of this one-sided notion of integration entirely on the new arrivals, while seemingly disregarding a more pluralistic model of multiculturalism. Birgit Baindl admits, "Wir kriegen gelegentlich Beschwerden von Nachbarn, dass wir das abstellen sollen. (Occasionally, we get complaints from neighbours, saying that we should shut that off.)" (Hackl, n. p. My emphasis) This quote is placed in a text box following the opening description of trash scattered around the asylum housing complex, and since it goes on to refer to recycling and trash removal, the "that" contextually seems to refer to the trash problem. Yet, the ambiguity of this vague referent together with the collective subject "we" and a verb that "puts a stop to" or "turns off"11 behaviours like a faucet not only makes environmentalist adherence appear as a direct path to societal appeasement (rather than the protection of the planet), but also suggests that the problem identified with "that" is not the presence of trash, but the refugees themselves.

One might imagine that the neighbours would be more welcoming once the trash disappeared, but this outcome is curiously absent from the text. The article indicates that the program is working well, yet rather than, for example, measuring its success in reduced environmental impact, it focuses exclusively on its function in reducing potential social tensions: the mostly single younger men who participate are now kept busy in their daily lives by their new jobs as environmental experts, which "strukturiert den Alltag (gives structure to their everyday life)" (Hackl, n. p.) - that is, they are presumably kept occupied in order to prevent them from getting into trouble with the locals and the law. At this point another concern emerges, namely the

\footnotetext{
${ }^{11}$ Abstellen in this sense also translates into "suppress," but is more frequently used in the context of "shutting off" utilities such as water, gas, and electricity, or "turning off" the music, radiator, stove, and tap. In addition, abstellen can mean "to set down" a heavy load and "to place" or "park" something, potentially evoking the notion of putting out the trash or getting rid of something unwanted (cf. Abstellraum=storage room).
} 
conservation of financial resources, which is blurred with the aforementioned notion of the "protection of resources" in an environmental sense. Initially, it seems that the German government is expending, rather than conserving, an unusual amount of resources on this particular project: despite their undetermined status in the asylum process, which means that they are lacking a work permit, the participants in this program have special permission to be paid for their jobs - yet another way to keep them out of trouble. ${ }^{12}$ Yet the program's emphasis on independent research and local excursions appears very costeffective, and the creation of a few refugee experts means that no translators and teachers need to be hired - and paid presumably much better than the refugee's marginal employment ${ }^{13}-$ for the environmental education of large numbers of asylum seekers. Additional potential for savings is only alluded to when the article describes that "Die Heizungen in den Flüchtlingsunterkünften laufen die ganze Zeit auf Hochtouren. Die Temperatur wird durch Öffnen und Schließen der Fenster geregelt. All das ist kostspielig und verschwenderisch. (The radiators in refugee housing are constantly running at full heat. The

\footnotetext{
${ }^{12}$ While the efforts of equipping members of the refugee community for independent work and the exceptions to asylum law show the great importance placed on environmental education by the German government, it is problematic that the financial incentive of the program seems to be the only available means of earning money for asylum seekers - and even then only for a select few. This introduces an additional inequality to an already difficult situation, which the article seems to underline through the absence of women holding certificates in the "graduation image." However, the project's own description on www.umweltbildung-mit-fluechtlingen.de includes a more diverse picture of graduates and uses overall much more nuanced language. In contrast to the article, the website also makes a point of explaining that no German knowledge is required for the program, instead relying on communication "mit Händen und Füßen (with hands and feet)," which, however, suggests an absence of potentially expensive translators and specialists even in the program itself.

${ }^{13}$ The refugees hold a so-called Minijob, a type of employment whose payment or duration are limited (see www.minijob-zentrale.de for the most recent regulations).
} 
temperature is regulated by opening and closing the windows. All that is pricy and wasteful.)" (Hackl, n. p.) Here too, the program's successful outcomes would blend the conservation of environmental resources, like energy, with the financial benefit of the government agency that foots this utility bill (and by imagined extension also lighten the burden of the taxpayer reading the article).

The two newly certified refugee experts featured in the article confirm the program's success by expressing that they gained valuable insights, though notably, neither of them relate their expertise explicitly to their local environment in Germany in these excerpts. Raphael from Nigeria explains the destructive effect of plastic waste on the oceans of the world, while Mourana from Sierra Leone suggests that the government of his home country should become more interested in solar energy (Hackl). ${ }^{14}$ Few articles about initiatives for refugees that involve environmental education mention the world beyond Germany, and if they do, the potential of successfully transferring environmentalist practices into the context of the refugees' home countries is usually brought up by refugee voices. The fact that mass migration and environmentalist concerns - such as climate change - are interconnected phenomena that will increasingly have an impact on our shared future seems to fade into the background in favor of the transmission of specifically German notions of environmentalism. ${ }^{15}$ One exception is the Umweltmagazin (Environmental Magazine) regularly published by the section for Umwelt- und Klimaarbeit (Environmental and Climate Work) of the Evangelisch-Lutherische Kirche in Bayern (Protestant Church of Bavaria). Its July 2016 special edition is dedicated to the topic of "Umwelt. Flucht.

\footnotetext{
${ }^{14}$ A reason for the absence of the last names of the participants is not given in the article, and though it might be to protect their privacy vis-à-vis their country of origin, it does have the distinct effect of not granting the same respect of a formal address to the two adult men that is given to all the other cited voices (which belong to non-refugees).

${ }^{15}$ A good overview of the connections between recent refugee movements from Syria and climate change is given by Randall.
} 
Unser Beitrag" (Environment. Migration. Our Contribution). The articles in the volume approach matters of environmentalism and migration from a wide range of historical and geographical perspectives and thereby contextualize the phenomenon in a larger global and temporal context: by learning from the past one may prepare for the future.

Some contributions to this volume also feature contemporary environmental initiatives involving refugees in Germany, but, importantly, they describe some practical problems that arise in those encounters, rather than mainly reporting programmatic success. One event they describe, for instance, was planned as an evening of locals and refugees cooking and sharing their favourite meals. The ingredients were supposed to be organic, local, and vegetarian (the latter in order to save money and avoid issues with dietary restrictions). Though the event turned out to be successful, it was difficult to realize. Since none of the refugees spoke German or English, except for one person, and the event was organized by volunteers who did not speak any of the refugees' languages, several aspects did not go as planned: the recipes for non-German dishes came not from the refugees but the internet, and they were written in German. Several ingredients were not accepted by the refugees (such as a spice mixture prepared by some of the volunteers) and one group went to buy meat to complete their dish. Cooking with nearly 30 people in one kitchen without the ability to communicate was complicated and took much longer than planned, and in the end, most diners sat in groups of people with whom they could communicate, thus hampering the interaction between locals and refugees. Most notably, some refugees initially took the event to be a test of some sort and were incredibly nervous (Rittershofer). The honest list of practical snafus in this article offers a glimpse at the challenges behind all the innovative ideas and initiatives. It shows that cultural differences unfold in practice and that it is challenging to change habits with theoretical instruction alone: this comes out most clearly in the different value placed on meat in this situation, which one refugee group saw as essential to an authentic 
dish to be served to "guests" (in this case the locals), while the local hosts had decided to focus on vegetarian fare, so they would not offend any of their "guests" (the refugees), but also in order to promote local, organic, vegetarian values and save money. Ultimately, mutual good intentions prevailed, but as with any of the projects, this relies on a shared willingness to learn from each other in a dialogic manner. While the many programs for refugees create important spaces of encounter, the above list of "failures" makes the case that the push to teach refugees cultural values also needs to include a designated space for locals to learn about cultural differences by involving refugees as experts in decision-making and planning processes.

Admitting difficulties made this article stand out, and its honest appraisal proved much more helpful than the host of success stories that serve many functions in the press, from information transfer and inspiration to start one's own initiative, to feel-good journalism and the appeasement of those German groups that have not been as welcoming to refugees. ${ }^{16}$ There is also media coverage about German environmentalism and refugees that takes an openly negative tone. Media outlets on the far right of the political spectrum proclaim that „refugees are destroying environmentalism" (Redaktion, n. p.), while simultaneously faulting environmentalists in general and the Green Party in particular for its welcoming stance toward asylum seekers. Depicting single incidents as widespread practices and engaging in overt fear-mongering, the article with the abovecited headline lists offenses such as the poaching of local wildlife for food and - of course - the lack of proper recycling technique as threats to the German way of life in the wake of what it calls the "Asyl-Tsunami (asylum tsunami)" (Redaktion, n. p.). It concludes by reprinting an excerpt from Die Asyl-

\footnotetext{
${ }^{16}$ The website of Umweltbildung mit Flüchtlingen lists the production of postcards about its refugee initiatives as one of its projects and measures its success, at least partly, in its news coverage, which signals the perceived importance of positive press about refugees in Germany ("Postkarten zur Umweltbildung mit Flüchtlingen").
} 
Industrie (The Asylum Industry) by questionable bestselling author Udo Ulfkotte, in which he bemoans the loss of Germany's status as one of the "cleanliest" of nations, making explicit connections between non-Germans and impurity, faeces, and trash. Unfortunately, recycling's principle of separating like from other is easily co-opted for fascist ideology, particularly in the context of cultural outsiders. It is crucial to keep this in mind when touting the importance of recycling as a cultural value and as a key to successful living together.

The news coverage of environmentalist initiatives for recent refugees tells us more about German cultural values than about refugees or the protection of the environment. It brings to light many issues, such as the idea that German environmentalism is the path to a problematic notion of "integration" and constitutes a universal abstract good despite its apparent localism. At the same time this coverage conceives of refugees as a homogenous group whose own cultural and environmental practices are mostly elided. Yet, regardless of tone-deaf media reporting and unfortunate formulations, it is important to emphasize that these initiatives do important work in bringing together current and future citizens and in helping to convey a sense of the cultural importance of environmentalism in Germany to new arrivals. Just as it seemed counterintuitive for the Spiegel TV documentary mentioned in the beginning of this article to look for behaviours that "hurt the environment" in the environmental infrastructure of a green leader like Germany, it seems ungenerous to critique these well-intended efforts to welcome refugees. Rather, this article sought to make apparent cultural conceptions of environmentalism and their local idiosyncrasies in the German context, and it pointed to the many inadvertent side effects and downsides of the complicated task of transmitting cultural values and practices by examining the nuances and complexities of the status of environmentalism within these encounters. 


\section{Works Cited}

Amjahid, Mohamed, Christian Fuchs, Vanessa Guinan-Bank, Anne Kunze, Stephan Liebert, Sebastian Mondail, Daniel Müller, Yassin Musharbash, Martin Nejezchleba, and Samuel Rieth. "Was geschah wirklich?" Zeit Magazin, no. 27, 2016, 28 June 2016, http://www.zeit.de/zeit-magazin/2016/27/silvesternacht-koelnfluechtlingsdebatte-aufklaerung Accessed 26 Feb. 2017

Arbeitsgemeinschaft Natur- und Umweltbildung Bayern. "Alle Projekte von A-Z." http://umweltbildung-mit-fluechtlingen.de /praxisbeispiele/alle-projekte-von-a-z/ Accessed 26 Feb. 2017

Arbeitsgemeinschaft Natur- und Umweltbildung Bayern. "Postkarten zur Umweltbildung mit Flüchtlingen.” http://umweltbildung-mitfluechtlingen.de/willkommen/newsdetail/news/postkarten-zurumweltbildung-mit-fluechtlingen/ Accessed 26 Feb. 2017

Arbeitsgemeinschaft Natur- und Umweltbildung Bayern. "Umweltbildung mit Flüchtlingen." http://www.umweltbildung-bayern. de/fluechtlinge.html?PHPSESSID=b993cb0072e526abc527275e5 19ee814 Accessed 26 Feb. 2017

Beauftragter für Umwelt- und Klimaverantwortung der EvangelischLutherischen Kirche in Bayern (ed.). Umweltmagazin: Umwelt.Flucht.Unser Beitrag. No. 73, July 2016

http://www.umwelt-evangelisch.de/umwelt-mitwelt-

zukunft/send/14-umwelt-mitwelt-zukunft-das-magazin/199umwelt-flucht-unser-beitrag-um-73. Accessed 26 Feb. 2017

Bundesministerium für Arbeit. "FAQ: Zugang zum Arbeitsmarkt für geflüchtete Menschen.” http://www.bamf.de/DE/Infothek/Fragen Antworten/ZugangArbeitFluechtlinge/zugang-arbeit-fluechtlingenode.html Accessed 26 Feb. 2017

Dallmus, Alexander. "Der Bayern 1-Umweltkommissar: Joghurtbecher spülen oder nicht?" Bayerischer Rundfunk, 2 Oct. 2013, http://www.br.de/radio/bayern1/inhalt/expertentipps/umweltkommissar/joghurt-becher-spuelen-gelber-sackabfall-umwelt-100.html Accessed 26 Feb. 2017

Deutsche Bundesstiftung Umwelt. "Ausschreibung im DBUProgramm Umwelt und Flüchtlinge." Newsletter DBUaktuell, no. 
III, 2015, https://www.dbu.de/1254ibook76500_36460_2487. $\mathrm{html}$

Deutsche Rentenversicherung Knappschaft-Bahn-See. Die Minijobzentrale. https://www.minijob-zentrale.de/ Accessed 26 Feb. 2017

EcoMENA. http://www.ecomena.org/ Accessed 26 Feb. 2017

"Einsatz für ein sauberes Heidelsheim." Kraichgau News, no date, http://kraichgau.news/bretten/soziales/einsatz-fuer-ein-sauberesheidelsheim-d307.html Accessed 26 Feb. 2017

Hackl, Herbert. "Recyclingkurse für Migranten: Mühsame Müllregeln." Bayerischer Rundfunk, 30 May 2016, http://www.br.de/nachrichten/migranten-umwelt-bildung102.html. Accessed 26 Feb. 2017

Hummitzsch, Thomas. "Flüchtlinge in Deutschland: Isolation und Rassismus ausgeliefert." Diesseits. 27 Feb. 2013, http://www.diesseits.de/panorama/rezensionen/1361919600/fluec htlinge-deutschland-isolation-rassimus-ausgeliefert Accessed 26 Feb. 2017

Ki-moon, Ban. "Forced Displacement: A Global Challenge." United Nations, 15 Apr. 2016,

http://www.un.org/press/en/2016/sgsm17670.doc.htm Accessed 26 Feb. 2017

Klovert, Heike. "Flüchtlinge und deutsche Frauen: Eine Armlänge Unsicherheit." Spiegel Online, 19 Apr. 2016, http://www.spiegel.de/lebenundlernen/schule/polizei-zufluechtlingen-von-deutschen-frauen-einen-arm-abstand-a1085801.html. Accessed 26 Feb. 2017

Messerschmidt, Achim. "Flüchtlinge lernen Mülltrennung: Hilfe bei den Hürden des Alltags." Eckernförder Zeitung, 15 Oct. 2015, http://www.shz.de/lokales/eckernfoerder-zeitung/hilfe-bei-denhuerden-des-alltags-id10956726.html. Accessed 26 Feb. 2017

"Müll sammeln als Dankeschön." Usinger Anzeiger, 29 Feb. 2016, http://www.usinger-anzeiger.de/lokales/weilrod/muell-sammelnals-dankeschoen_16682424.htm. Accessed 26 Feb. 2017

Neubacher, Alexander. "Der Ökofimmel: Wie Umweltschutz der Umwelt schadet: Teil 1: Mülltrennung für Fortgeschrittene." Spiegel TV Magazin. 31 Dec 2012 
http:/www.spiegel.de/video/umweltschutz-kann-der-umweltauch-schaden-video-1242632.html Accessed 26 Feb. 2017

Randall, Alex. "Syria and Climate Change: Did the Media Get it Right?" Climate and Migration Coalition, no date, https:/climatemigration.atavist.com/syria-and-climate-change Accessed 26 Feb. 2017

Redaktion. "Panik bei den Grünen: Flüchtlinge machen Umweltschutz zunichte." Kopp Online, 28. Sept. 2015, http://info.koppverlag.de/hintergruende/deutschland/redaktion/panik-bei-dengruenen-fluechtlinge-machen-umweltschutz-zunichte.html Accessed 26 Feb. 2017

Reimann, Anna. "Muslime in Deutschland: 'Wer auf andere losgeht, hat sein Asylrecht verwirkt" Spiegel Online, 10 Sept. 2015, http://www.spiegel.de/politik/deutschland/syrien-effekt-wieveraendern-fluechtlinge-den-islam-in-deutschland-a1051934.html Accessed 26 Feb. 2017

Rittershofer, Michael. "Chicken? Chicken! Kochen mit Flüchtlingen bei TAGWERK e.V. - Eine vorläufige Bilanz.” Umweltmagazin: Umwelt.Flucht.Unser Beitrag, edited by Beauftragter für Umwelt- und Klimaverantwortung der Evangelisch-Lutherischen Kirche in Bayern, no. 73, July 2016, pp. 13-14, http://www.umwelt-evangelisch.de/umwelt-mitweltzukunft/send/14-umwelt-mitwelt-zukunft-das-magazin/199umwelt-flucht-unser-beitrag-um-73 Accessed 26 Feb. 2017

Simmons, Daisy. "Myth: You Must Rinse All Recyclables, Or Else!" Ecomyths Busted, 30 Oct. 2013, https:/ecomyths.org/2013/10/30/myth-you-must-rinse-allcontainers-before-recycling-them/. Accessed 26 Feb. 2017 Speck, Melanie. Konsum und Suffizienz: Eine empirische Untersuchung privater Haushalte in Deutschland. Springer, 2016.

Technische Betriebe Solingen. "Abfall ABC." http://www2.solingen.de/C125739700644139/htm1/0AC02D6B1 BFD823DC1257AB0004D6789?opendocument Accessed 26 Feb. 2017 
Tierney, John. "The Reign of Recycling." The New York Times, 3 Oct. 2015, http://www.nytimes.com/2015/10/04/opinion/sunday/ the-reign-of-recycling.html?r=0 Accessed 26 Feb. 2017

Ulfkotte, Udo. Die Asyl-Industrie: Wie Politiker, Journalisten und Sozialverbände von der Flüchtlingswelle profitieren. Kopp, 2015.

Verband für bürgernahe Verkehrspolitik e.V. "Bußgeldkatalog 2016: Müll und Müllentsorgung."

https://umwelt.bussgeldkatalog.org/muell/ Accessed 26 Feb. 2017

"Verbrannt statt wiederverwertet." Zeit Online, 18 Oct. 2016, http://www.zeit.de/wissen/umwelt/2016-10/recycling-verbranntstatt-wiederverwendet Accessed 26 Feb. 2017

Verein Menschen leben. "Recycling als neue Erfahrung." http://www.menschen-leben.at/recycling-als-neue-erfahrung/ Accessed 26 Feb. 2017 